DOI: $10.31866 / 2410-1915.22 .2021 .235914$

UDC 78.011.26:78.071.2]:[7.05:687.016

\title{
STAGE IMAGES OF ROCK MUSICIANS AND THEIR INFLUENCE ON THE FORMATION OF MODERN TRENDS IN CLOTHING DESIGN
}

\author{
Kateryna Kyselova ${ }^{1 \mathrm{a}}$, Olha Shandrenko ${ }^{2 \mathrm{a}}$, Alina Shcherbak ${ }^{3 \mathrm{a}}$ \\ ${ }^{1} \mathrm{PhD}$ in Engineering, Associate Professor, \\ ORCID: 0000-0002-1580-287X, katerinakiselova@gmail.com, \\ ${ }^{2} \mathrm{PhD}$ in Art Studies, Associate Professor, \\ ORCID:0000-0001-5284-7252, shan.olga77@gmai.com, \\ ${ }^{3}$ Master, \\ ORCID: 0000-0002-5484-5354, shcherbakalina@gmail.com, \\ ${ }^{a}$ Kyiv National University of Culture and Arts, \\ 36, Ye. Konovaltsia St., Kyiv, 01133, Ukraine
}

\section{For citations:}

Kyselova, K., Shandrenko, O., \& Shcherbak, A. (2021). Stage Images of Rock Musicians and their Influence on the Formation of Modern Trends in Clothing Design. Culture and Arts in the Modern World, 22, 199-211. https://doi.org/10.31866/2410-1915.22.2021.235914.

The purpose of the article is to reveal the influence of stage images of rock musicians on fashion design trends formation. Research methodology: the authors of the article use methods of source study analysis to determine the level of scientific development of the issue, comparative historical analysis to identify the characteristic features of images of musicians and catwalk models of clothing collections of famous designers, and theoretical generalization to draw conclusions. The scientific novelty of the work is to highlight the influence of stage images of musicians on the formation of modern trends in fashion design. The analysis of genre affiliation reveals stylistic differences of the stage costume of popular musicians of the USA and Europe. Some stylistic characteristics of the artists' stage clothing could be traced in the collections of famous fashion brands of the $21^{\text {st }}$ century, such as Balenciaga, Philipp Plein, Vetements, Alexander Wang, Alexander McQueen, and others. Conclusions. The research reveals the main stylistic features of the stage costume of hard rock and heavy metal musicians. Stage images of artists were innovative and widely used in fashion design of the $20^{\text {th }}$ and early $21^{\text {st }}$ century. The active influence of musicians on fashion trends began in the 60 s and 70 s of the twentieth century, which coincided with the development of stage costume design and the significant spread of media technology. Hard rock and heavy metal performers created and popularized such a style direction as "grunge", which is one of the leading musical trends in 2020-2021. Designers of the $21^{\text {st }}$ century borrowed many details, visual and stylistic features, and even concepts for brands from popular hard and heavy artists of the 1970s-1990s. Stage images of rock musicians have a significant impact on the development of fashion and design. Keywords: stage costume; fashion; trends; history of music; rock music; clothing design

(C) Kateryna Kyselova, 2021

(C) Olha Shandrenko, 2021

(C) Alina Shcherbak, 2021

The article was received by the editorial office: 07.04.2021 


\section{Introduction}

Problem statement. The musical culture of the late twentieth century is a whole epoch that influenced not only the cultural and philosophical aspects of modern life, but also fashion and design. At the end of the twentieth century, Europe and America have experienced a wave of popularity of such musical genres as hard rock and heavy metal. They became the mouthpiece of the youth of that period and brought society to a new evolutionary level of culture and self-expression. Under the influence of the revolutionary musical culture, the appearance standards of young people have undergone significant changes. Everyone wanted to feel uninhibited and free. Since the younger generation demanded the realization of their individuality, the expression of their own views, and the desire for identity, it was hard rock and heavy metal that appeared to be able to help them.

Fashion to imitate the appearance of rock musicians facilitated the adaptation of these genres in society. This trend turned out to be quite stable and has remained popular for almost 50 years. Today, a large number of designers and brands successfully use the stylistic features of stage costumes of hard rock and heavy metal performers, as well as images of the subcultural trends of the twentieth century generated by them. The catwalks combine music and fashion contributing to the constant restoration of hard rock and heavy metal trends that require research and systematization.

Recent research and publications analysis Scientific research and historiographical material on the influence of hard rock and heavy metal genres on fashion design do not sufficiently reveal the development and mutual influence of the fashion and music industries. Researchers mainly study the work of certain musical groups, pay attention to the appearance of performers (Leonard, 1989; Leaf \& Sharp, 2003; Mann, 2019; Simmons \& Stanley, 2002) or the overall impact of rock music on culture (Shepherd et al., 2003). Among the researchers are the names of Velichko (2013) and Gutov (2014), Leaf \& Sharp (2003), Mann (2019). Researchers and authors of the European and American specialized and popular publications Kummer (2016), Mirabella (2017), Smith (2018) dealt with the influence of hard rock and heavy metal music on fashion. Sue Jenkyn Jones (2011) and Josh Sims (2001) focus on the overall dominant role of music, illustrating research with photos of fashion trends emerging from the rock music era. Sue Jenkyn Jones (2011) defines music as an inspiration factor in the fashion world. He emphasizes that designers are forced in one way or another to follow the dictatorship of trends that come from the culture of fans of certain genres of music. Morrell Ernest (2004) proves the influence of music on fashion on the example of teen urban culture in the United States. Blackwell \& Stephan (2004) explain that both music and fashion affect everyone, and the success of a music-inspired fashion trend is ensured by a variety of performances, concerts, as well as wide media coverage. This conclusion was made based on the interviews with one hundred well-known people from both fields. The equal mutual influence is proved by Aram Sinnreich and Marissa Gluk (2005) and Smith (2018). The authors write that music and fashion are two creative 
trends that have a lot in common and develop in parallel throughout history. Some researchers compare the stage images of individual performers and fashion trends. Blackwell \& Stefan (2004) described the band Kiss, and Mann (2019) - the band Guns N' Roses. Shcherbak and Kyselova attempted to consider the citation of the musicians' images in the $21^{\text {st }}$ century fashion (Shcherbak \& Kyselova, 2019).

But mostly, the influence of hard rock and heavy metal genres on fashion is not analysed in detail, and the impact of the performers' stage images on the $20^{\text {th }}$ and $21^{\text {st }}$ centuries fashion is covered sporadically. Considering the importance and insufficient research on the influence of the musical genres of hard rock and heavy metal on fashion design, the article attempts to identify common features between the stage image of hard rock and heavy metal performers and fashionable images of the $20^{\text {th }}-21^{\text {st }}$ centuries.

\section{Purpose of the article}

The purpose of the article is to reveal the influence of stage images of rock musicians on fashion design trends formation.

\section{Main research material}

The 1980s are considered one of the most important decades in the music industry. At this time, the hard and heavy genre gained the greatest popularity. Guns N' Roses band is one of its brightest representatives. The stage images of the performers were unusual and very bright and at the same time not devoid of the features of everyday life. And though today this is perceived as something common, then it was really an innovation. The musicians complemented everyday items - denim and leather jackets, trousers and T-shirts with or without sleeves - with bandannas and top hats. It was a challenge to the established rules and fashion of that time, it was even more like a protest against neatness and completeness, as well as the need for careful selection of things and thinking through the stage wardrobe. Musicians have made semi-everyday images a key component of their success, but other bands have also realized that they don't have to put a lot of effort in choosing their stage costumes, as they did in the early 1970 s.

In 1991, during the presentation of the double album "Use Your Illusion", vocalist Axl Rose surprised everyone again by wearing clothes for playing American football or a Scottish kilt with a bulletproof vest on the stage. These borrowings of sports and military clothing and unconcealed eclecticism quickly resonated on the catwalks. The apogee of the protest against any norms was narrow white shorts that were too tight (they are part of the costume in the music videos "You Could Be Mine" and "Live and Let Die"). The artist in these shorts defiantly demonstrated that he did not care what to wear on stage, even if underwear. There was something about it from punk fashion and punk rock philosophy, not only a protest, but also a rejection of any imposed trends and ideas (Otkydach, 2008). "Dress the way you want, the way you feel comfortable, 
bring maximum individualism that is not subject to trends or general rules" this was the message to future rock bands, singers, and most importantly fans, such a vector of the way to express yourself as freethinkers. The huge popularity, wide coverage of the work of Guns N' Roses in music videos, and active concert activities significantly contributed to the promotion of this philosophy among young people. The images of success were so appealing that they easily convinced a huge number of fans that bandannas and leopard prints in clothing were a good idea for self-expression. Researcher Barbara Mann (2019), in a book dedicated to the work of Guns N' Roses, notes that starting from the 1980s almost every fashionista had their merch.

Axl Rose made clothing an integral part of his work, he was an artist-innovator who not only had a good ear for music but also a good taste, none of his images were repeated. Axl constantly experimented, combining what at that time seemed incompatible - everyday things with sports, military, classic, and fantasy, comfortable denim clothes with bright accessories, massive sneakers. T-shirts or shirts with inscriptions and illustrations, oversized bright jackets co-existed with fur coats or jackets of bright colours and were complemented by massive riveted belts or cowboy hats, bandannas, and caps worn backwards. And if in the early 1980s his way of dressing was considered more eccentric and extravagant than fashionable, since the mid-1980s, his images were copied not only by fans, but also by some representatives of the creative elite of America, including pop stars of the 1990s and 2000s Christina Aguilera and Gwen Stefani.

There is no doubt that Guns N' Roses led by Axl Rose had a huge impact on generations of young people, and today their images are still echoed on the catwalks. We can say that Guns N' Roses stands out from other bands for their unusual approach to fashion, they shaped it rather than imitated it. Axl's branded bandanna, tied around the head, has become a real fashion fetish and has been holding its triumphant procession for almost 40 years.

Marita Mirabella (2017) describes the spread of heavy metal music as a phenomenon of globalization. "Heavy metal is a peculiar music genre, made by fans for fans, which spread throughout the entire planet and became, over its five decades of existence, a global community as well" (p. 61).

The next striking example of "metal fashion" was the British band Judas Priest, which, in addition to innovation in sound, is known for its revolutionary status in creating stage images of heavy metal artists (Leonard, 1989). Their impact on society is confirmed by the popularity of their albums, the number of copies sold was over 50 million (Bleckwell \& Stephen, 2004). In 1980, after the release of the album "British Steel", they became superstars. In the early years of their existence, the band dressed in hippie costumes of the 1970s, but in 1978 guitarist K. K. Downing, and in 1979 Rob Halford, the band's lead vocalist and leader, replaced their outdated images by wearing leather and spikes inspired by punk fashion and "leather culture".

The image of Rob consisted of leather jackets or vests, leather trousers, and many accessories in the form of wide bracelets, belts, and chains. All this was complemented by a leather cap (which resembled the headdress of SS officers) 
and sometimes aviator sunglasses. A lot of metal spikes and rivets covered all clothing and accessories. He appeared on the stage riding a real bike and performed with a whip. This image became his trademark and an icon for heavy metal artists. In the early 1980s, this style of dress was adopted by many heavy metal bands and their fans, especially by such movements as NWOBHM (abbreviation for "new wave of British heavy metal") and early black metal, and also led the entire heavy metal culture (Gutov, 2014). Rob later admits that he had to buy almost everything in sex shops and departments with BDSM costumes.

Speaking of the mutual influence of music and fashion, we should mention the legendary and very popular stage images of the band Kiss, the founders of such subgenres of heavy metal as glam metal and shock rock. The popularity of this band in the world of metal music can only be compared with the success and popularity of Michael Jackson, that is, in the 1970s and 1980s, a wave called "Kiss" swept the whole world (Simmons \& Stanley, 2002).

Kiss is unique in that it was the first band that created not just stage images, but their own characters, such as previously were created only by directors in films. The band members seem to play hyperbolized themselves in inhumane images. Almost every member of the band has about 5-9 different costumes. As a rule, they have 3-5 main costumes, or permanent ones, which they have been wearing almost since the beginning of their careers in the 1970s. Basically, these are close fitting jumpsuits or tights made of black and silver spandex with important modular and decorative elements that are crucial for their characters. So, Paul Stanley (frontman) has an image called "The Starchild", Gene Simmons (bass guitarist) - "The Demon”, Paul Daniel Fraley (guitarist) "Spaceman".

Stanley's torso is always almost naked. The costumes are as light and tight as possible, without any massive elements. Most often, costumes are decorated with many stars, as one around his eye, in the form of stripes and decoration. The character of Gene Simmons (bass guitarist) "Demon", is the most aggressive in the band, known for his big tongue, demonic fire, and the stage blood he spits during concerts. The stage costume is usually similar to armour, has the most massive elements, which sometimes resemble a dragon costume, and sometimes a bat costume with leather wings from the elbows to the shoulders. As a man, who likes to shock the audience during concerts, Gene literally flew over the stage and hall. The next member of the band is "Spaceman" Paul Daniel Fraley (Leaf \& Sharp, 2003). His classic outfit is a tight black suit, which is worn with a vest made of geometric elements: a triangle, rings, and half-rings of silver colour. Make-up looks like silver glasses in the form of stylised stars. A passion for spandex, tight leather clothing, and aggressive makeup in the 1980 s is often associated with the popularity of this particular band.

So, in the 1970s and 1990s, we can easily trace the formation of the fundamental influence of the genres of hard rock and heavy metal music on fashion trends. The most powerful influence turned into the birth of the "grunge" style. It first appeared in the 1970s, but did not acquire its main features until the 1980s and 1990s. The term has been used to describe the work and clothing of many bands: Guns N’ Roses, Nirvana, Alice In Chains, Metallica, AC/DC, Judas 
Priest, Iron Maiden, and many others. Following the example of punks, hippies, and glam rockers, grunge fans stood out for their extraordinary appearance, minimally consistent with what is accepted in society. Deliberately faded T-shirts with old-fashioned logos, torn and aged jeans, flannel plaid shirts, woolen knitted sweaters and jackets with T-shirts under them became popular items of clothing. Leather, leather trousers and jackets, randomly scattered accessories with rivets and a lot of metal spikes, as well as bulky shoes resembling military ones, became the unchanging attributes of grunge. The grunge aesthetic has made clothing as comfortable and informal as it has never been before (Mann, 2019). This aesthetic has made thrift very popular. Many people started wearing this style of clothing because they couldn't afford another one. Even people with a very low income have become fashionable.

For quite some time, this style trend was the property of the streets and subcultures, but in his spring 1993 collection for Perry Ellis designer Marc Jacobs was the first to bring it to the catwalk. The collection was well ahead of its time, so it was heavily criticized, but now it is considered one of the most important in the brand's history. Dolce \& Gabanna, Anna Sui tried to experiment with this style direction in the 1990s, and since the 2000s Alexander McQueen, Balmain, Philipp Plein, Moschino, Alexander Wang, and many others. Now there are successful brands whose concepts are based entirely on citation of stage images of hard rock and heavy metal artists.

Philipp Plein is the first name that comes to mind if we talk about a designer who constantly introduces hard and heavy attributes on the catwalks. Just one look at any of his collections and the brand concept as a whole will be enough to understand that this is pure glam metal, which was so famous for the Kiss band in the 1970s and 1980s, or the famous style of the heavy metal band Judas Priest. Philipp Plein successfully interprets the entire philosophy of these genres in visual images. Since glam metal is the most provocative subgenre of heavy metal, its main idea is to express "disagreement" not only with the help of music, but also with an unusual appearance. Bright leather or tight-fitting clothing and accessories, the use of a large number of various inlays with zippers, spikes, rhinestones, stripes, massive shoes, an excess of details in the image. In his Spring 2019 Ready-to-wear and Spring/Summer 2020 Ready-to-wear collections, Philipp Plein skilfully uses these techniques and interprets them into modern fashion design (Fig. 1). The 2019 collection is more restrained in colours, its first blocks resemble the image of Judas Priest frontman Rob Halford in the 1970s (Fig. 2).

A large number of belts decorated with rivets and leather trousers are used in the models. The second half of the collection resembles the stage images of the band Kiss - large necklines on the chest, a lot of shiny things decorated with belts and rhinestones, high boots. The 2020 collection used many interesting design solutions, openly related to various hard and heavy bands (Fig. 3). For example, aggressive makeup, like the band Kiss, a lot of different chains, even the logos of bands and stylised musical instruments as accessories (Fig. 4). Also, the influence of heavy metal images can be traced in the brand's collections in 2014-2018. 


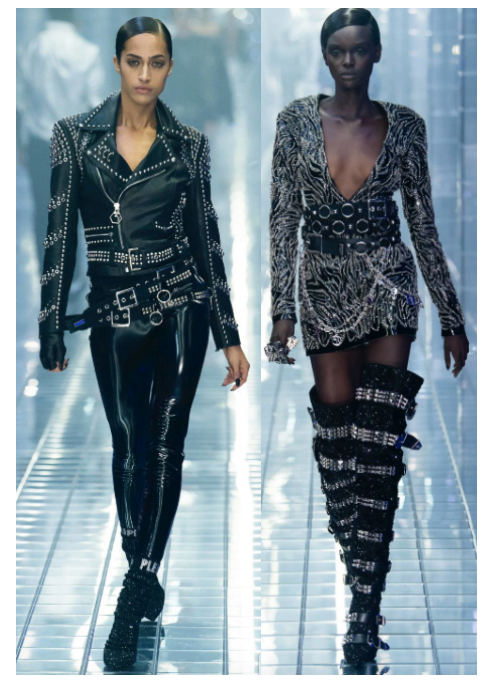

Figure. 1. Philipp Plein Spring 2019 Ready-to-wear collection models

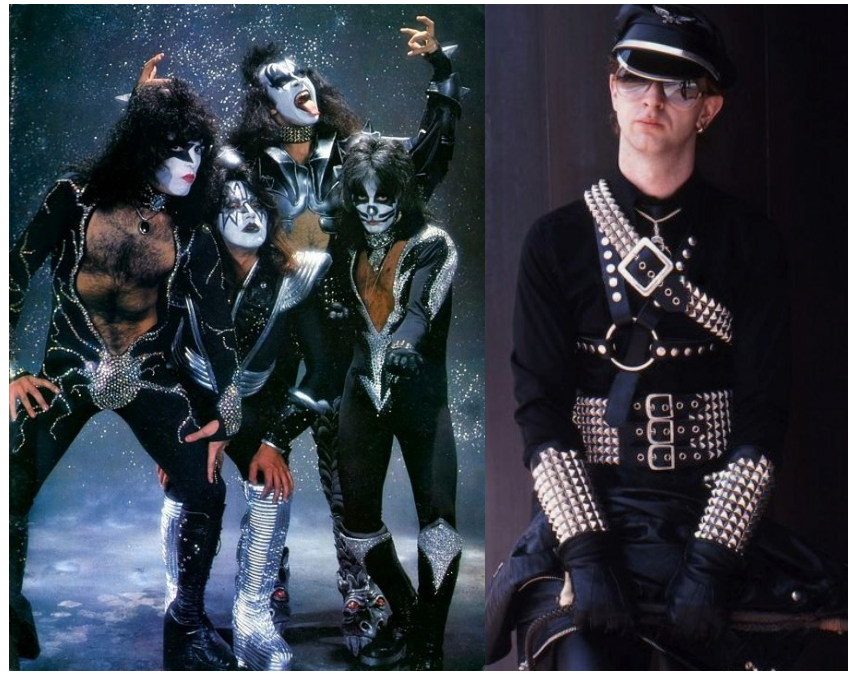

Figure. 2. Kiss band and Rob Halford, 1970s-1980s

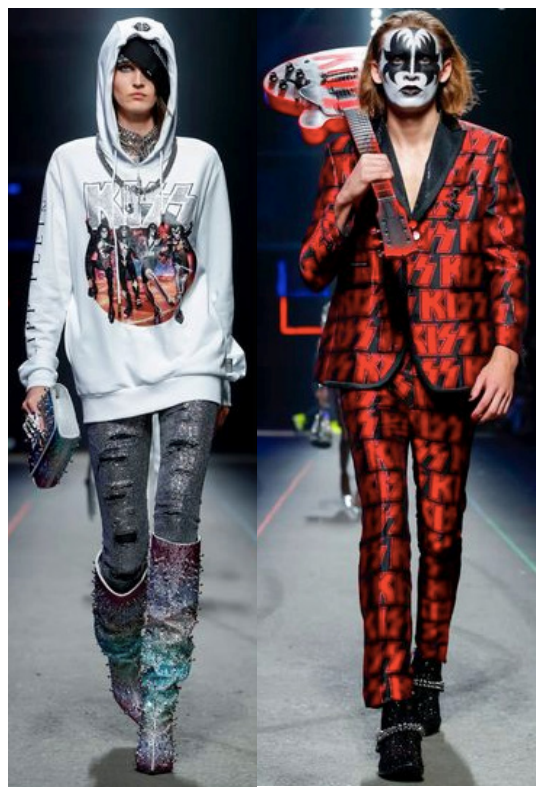

Figure. 3. Philipp Plein S/S 2020 Ready-to-wear collection models

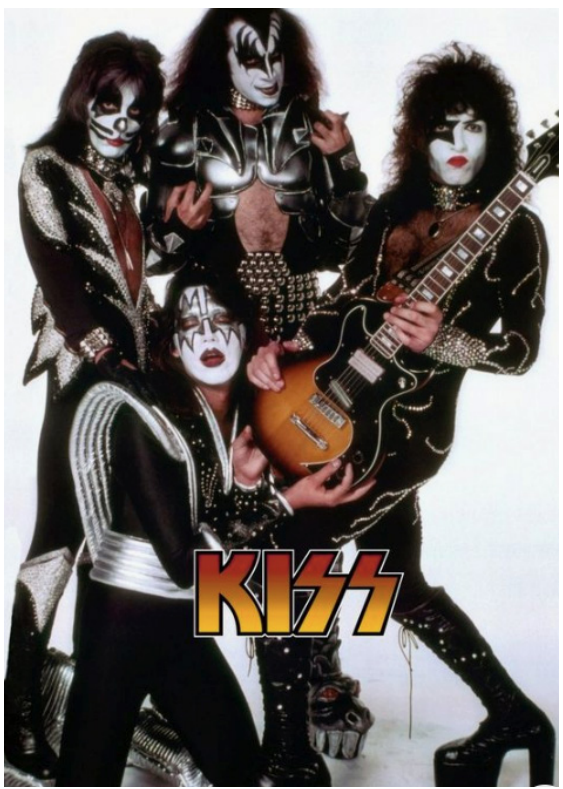

Figure. 4. Kiss band, the late 1970s

Another designer, who openly states that his main inspiration is music and its performers, is Alexander Wang. This is illustrated by his spring 2019 collection (Fig. 5) influenced by the style of Axl Rose (Guns N' Roses) and the movie 
"Mad Max" (Fig. 6). Almost all Axl Rose's popular images could be seen in each model. There are Axl's favourite bandannas tied around the head, leather and denim jackets or oversized jackets combined with short shorts, belts, or their imitation. Stylized basketball T-shirts, in which Axl appeared very often on stage, were also used. There are even models that have a kilt, which is one of the singer's favourite clothing elements.

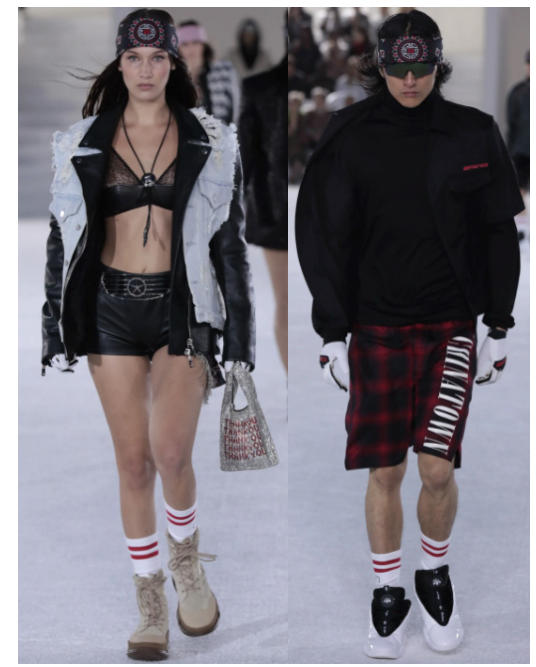

Figure. 5. Alexander Wang

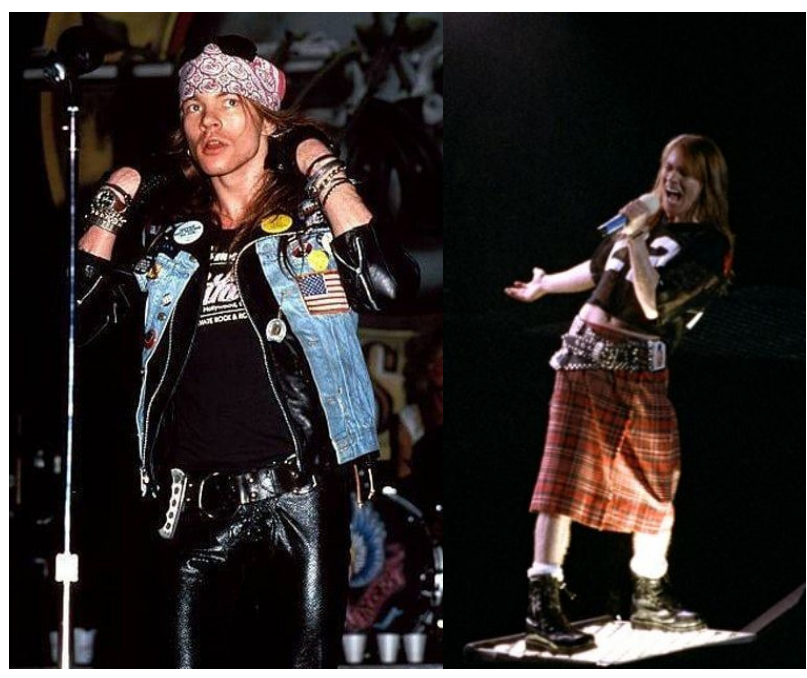

Figure. 6. Axl Rose, 1970s-1980s Spring 2019 collection models

It is worth mentioning the Alexander McQueen A/W 2019/2020 Ready-toWear Collection (Fig. 7). Almost the entire collection consists of outerwear. Attention is drawn to black leather raincoats, jackets with spikes and inserts of red and white leather on the sleeves and collars. Multi-layered skirts are worn under short leather jackets, complemented by combat boots with spikes and chokers around the neck. Outerwear inserts are very similar to Judas Priest costumes, and this is not the first time when the House of Alexander McQueen presents such collections (Fig. 8).

The famous Rick Owens brand is also one of those inspired by the glam metal style. The designer became famous as the creator of his own style direction in clothing, which he named "glange", a mixture of glamour and grunge. Being an eccentric and original designer, he shares his unusual vision of fashion and style, offering something completely unique and different in every his collection. Thus, in his Menswear Spring 2020 collection, he is inspired by the costumes of the band Kiss (Fig. 9).

Jumpsuits made of raincoat fabric are decorated with zippers, which have not only a functional, but also a decorative function. Members of the band Kiss wore almost the same costumes in the 1990s, but they were made of leather. There are also ankle boots with a very high platform and transparent heels, similar to the design of the shoes of the band Kiss (Fig. 10). 


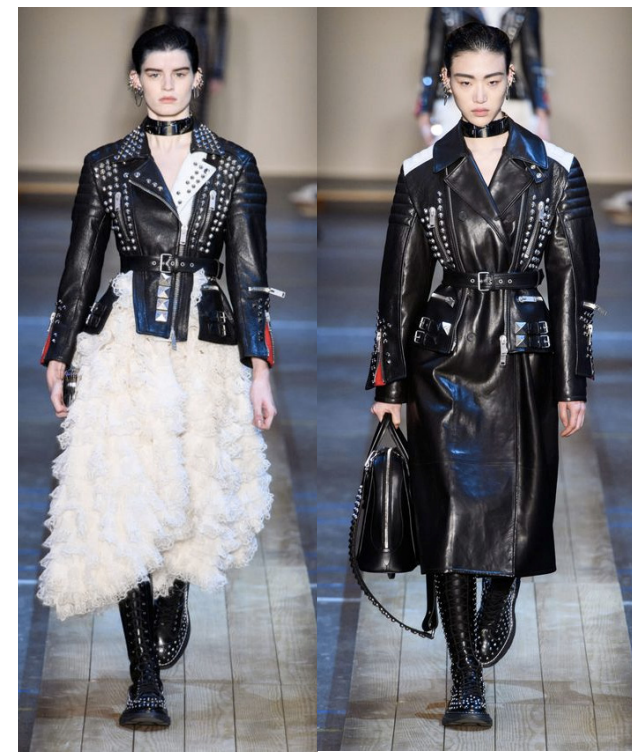

Figure. 7. Alexander McQueen A/W 2019/2020 Ready-to-Wear collection models

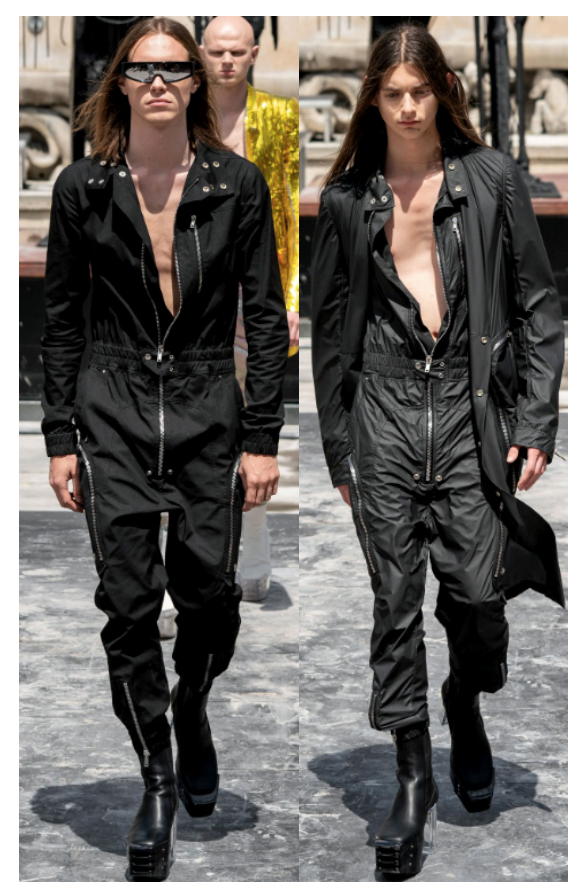

Figure. 9. Rick Owens menswear spring 2020 collection models

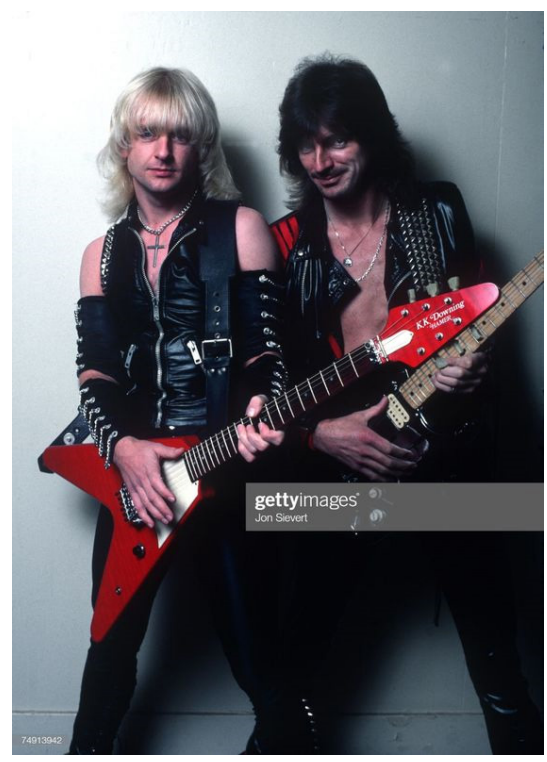

Figure. 8. Judas Priest band, the late 1970s

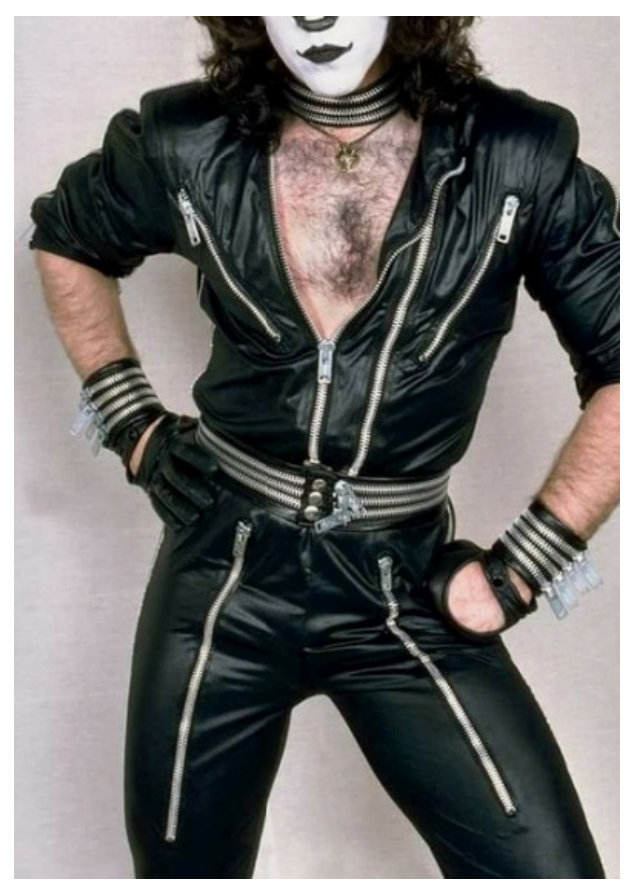

Figure. 10. Kiss band, the late 1980s 
In 2019-2020, such brands as Balmain, Versus, Pam Hogg, Moschino, FACETASM, 99\% IS, R13, Mooyul, Topman, Dilara Findikoglu, Jededldn, Comme des Garçons, Balenciaga, Vetements cited images of hard rock and heavy metal artists in their collections.

\section{Conclusions}

The research reveals the main stylistic features of the stage costume of hard rock and heavy metal musicians of the twentieth century. The article demonstrates that the stage images of artists were innovative and influenced the development of fashion design of the $20^{\text {th }}$ and early $21^{\text {st }}$ century.

The active influence of musicians on fashion trends began in the $60 \mathrm{~s}$ and 70 s of the twentieth century, which coincided with the development of stage costume design and the significant spread of media technology. Stage images of popular musicians were first imitated and introduced into the everyday wardrobe by their fans, which over time could not but draw the attention of the fashion industry. Hard rock and heavy metal performers created and popularized such a style direction as "grunge", which is one of the leading musical trends in 2020-2021. Designers of the $21^{\text {st }}$ century borrowed many details, visual and stylistic features, and even concepts for brands from popular hard and heavy artists of the 1970s-1990s.

The music industry has constantly influenced society and fashion. Each genre of music defines a decade when it is dominant, it imposes on listeners a specific type of behaviour, culture, subculture, and fashion trends. Stage images of musical artists significantly influence the development of fashion and design. Many fashion trends, being originated in the musical environment, continue to evolve, constantly updating and revealing new features in the work of modern designers, which requires systematic research.

\section{References}

Blackwell, R., \& Stephan, T. (2004). Brands That Rock: What Business Leaders Can Learn from the World of Rock and Roll. John Wiley \& Sons [in English].

Daniels, N. (2016). Judas Priest - A Metal Gods Scrapbook. CreateSpace [in English].

Gutov, E. V. (2014). Khevi-metal rok: opyt sistemnogo opisaniya [Heavy Metal Rock: an Experience of Systematic Description]. Vestnik Nizhnevartovskogo gosudarstvennogo universiteta, 1, 3-18 [in Russian].

Jones, S. J. (2011). Fashion Design ( $3^{\text {rd }}$ ed.). Laurence King Publishing [in English]. Kummer, J. (2016). "Lipstick and Leather": Recontextualizations of Glam Metal's Style and Signification. University of Lethbridge Research [in English].

Leaf, D., \& Sharp, K. (2003). KISS: Behind the Mask. The Official Authorized Biography.

Grand Central Pablishing [in English].

Leonard, H. (1989). Judas Priest - Metal Cuts. Hal Lenard Corporation [in English].

Mann, B. (2019). Guns and Roses: Adult Coloring Book: Famous American Rock'n'Roll Idols and Legendary Axl Rose, Iconic Guitar Axe Slash and Hard Rock Pioneers Inspired Adult Coloring Book. CreateSpace [in English]. 
Mirabella, M. (2017). Heavy Metal and Globalization Reception Study on the Metal Community in the Global South. Stockholm University [in English].

Morrell, E. (2004). Becoming Critical Researchers: Literacy and Empowerment for Urban Youth (Counterpoints). College Press [in English].

Otkydach, V. M. (2008). Rok-muzyka yak sotsiokulturne yavyshche [Rock Music As a Socio-Cultural Phenomenon] [Abstract of DSc Dissertation]. Kharkiv State Academy of Culture [in Ukrainian].

Shcherbak, A. Yu., \& Kyselova, K. O. (2019, March 20-21). Vplyv muzychnykh zhanriv khard-rok ta khevi metal na modu XXI stolittia [The Influence of Hard Rock and Heavy Metal Music Genres on the Fashion of the XXI Century]. In Ukraina u svitovykh hlobalizatsiinykh protsesakh: kultura, ekonomika, suspilstvo [Ukraine in the Globalization Processes: Culture, Economy, Society], Abstracts of Papers of the Internetional Scientific and Practical Conference (Pt. 2, pp. 52-56). KNUKiM Publishing Center [in Ukrainian].

Shepherd, J., Horn, D., Laing, D., Oliver, P., \& Wicke, P. (Eds.). (2003). Continuum Encyclopedia of Popular Music of the World: Media, Industry and Society (Vol. 1). Continuum Publisher [in English].

Simmons, G., \& Stanley, P. (2002). KISS: The Early Years. Plexus [in English].

Sims, J. (2001). Rock Fashion. Omnibus Press [in English].

Sinnreich, A., \& Gluck, M. (2005, January 29). Music \& Fashion: The Balancing Act Between Creativity and Control. Annenberg School for Communication [in English]. Smith, M. (2018). Grange Society. University of Michigan [in English].

Stanley, P. (2019). Backstage Pass (4th ed.). HarperOne [in English].

Velichko, I. V. (2013). Vzaimoproniknovenie muzyki khevi-metal i sovremennosti [The Interpenetration of Heavy Metal Music and Modernity]. Gumanitarnye vedomosti TGPU imeni L. N. Tolstogo, 1-2(5-6), 49-53 [in Russian].

\section{СЦЕНІЧНІ ОБРАЗИ РОК-МУЗИКАНТІВ ТА ЇХ ВПЛИВ НА ФОРМУВАННЯ СУЧАСНИХ ТРЕНДІВ У ДИЗАЙНІ ОДЯГУ}

Кисельова Катерина Олександрівна ${ }^{1 a}$, Шандренко Ольга Миколаївна ${ }^{2 a}$, Щербак Аліна Юріївна ${ }^{3 а}$

${ }^{1}$ Кандидат технічних наук, доцент, ORCID: 0000-0002-1580-287X, katerinakiselova@gmail.com, ${ }^{2}$ Кандидат мистецтвознавства, доцент, ORCID: 0000-0001-5284-7252, shan.olga77@gmai.com, ${ }^{3}$ Mazicmp, ORCID: 0000-0002-5484-5354, shcherbakalina@gmail.com,

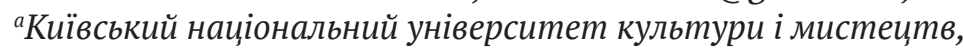
Київ, Україна

Мета статті - розкрити вплив сценічних образів рок-музикантів на формування трендів у дизайні одягу. Методологія дослідження: використано методи 
джерелознавчого аналізу для з’ясування рівня наукової розробленості проблеми, порівняльно-історичного для виявлення характерних особливостей образів музикантів та подіумних моделей колекцій одягу відомих дизайнерів, теоретичного узагальнення (для формулювання висновків). Наукова новизна роботи полягає у висвітленні впливу сценічних образів музикантів на формування сучасних трендів у дизайні одягу. На основі аналізу жанрової приналежності виявлено стилістичні відмінності сценічного костюма популярних музичних виконавців США та Європи. Окремі стилістичні характеристики сценічного одягу артистів простежуються в колекціях відомих модних брендів XXI століття, таких як Balenciaga, Philipp Plein, Vetements, Alexander Wang, Alexander McQueen та ін. Висновки. У процесі дослідження виявлені основні стилістичні ознаки сценічного костюма виконавців музичних жанрів хард-рок та хевіметал. Сценічні образи артистів були новаторськими і широко використовувалися у дизайні одягу XX та початку XXI століття. Активний вплив музичних виконавців на модні тенденції розпочався в 60-70-х роках XX століття, що збігається із розвитком дизайну сценічного костюма та значним поширенням медіа-технологій. Виконавці хард-року та хеві-металу створили та популяризували такий стильовий напрямок, як «гранж», який є одним із провідних у музичних тенденціях 2020-2021 рр. Багато деталей, візуально-стилістичних ознак та навіть концепцій для брендів дизайнери XXI століття запозичили у популярних хард-н-хеві виконавців 1970-1990-х. Сценічні образи рок-музикантів мають значний вплив на розвиток моди та дизайну.

Ключові слова: сценічний костюм; мода; тренди; історія музики; рок-музика; дизайн одягу

\section{СЦЕНИЧЕСКИЕ ОБРАЗЫ РОК-МУЗЫКАНТОВ И ИХ ВЛИЯНИЕ НА ФОРМИРОВАНИЕ СОВРЕМЕННЫХ ТРЕНДОВ В ДИЗАЙНЕ ОДЕЖДЫ}

Киселева Екатерина Александровна ${ }^{1 a}$, Шандренко Ольга Николаевна ${ }^{2 a}$, Щербак Алина Юрьевна 3 а

${ }^{1}$ Кандидат технических наук, доцент, ORCID: 0000-0002-1580-287X, katerinakiselova@gmail.com, ${ }^{2}$ Кандидат искусствоведения, доцент, ORCID: 0000-0001-5284-7252, shan.olga77@gmai.com, ${ }^{3}$ Mazucmp, ORCID: 0000-0002-5484-5354, shcherbakalina@gmail.com, ${ }^{a}$ Киевский национальный университет культуры и искусств, Киев, Украина

Цель статьи - раскрыть влияние сценических образов рок-музыкантов на формирование трендов в дизайне одежды. Методология исследования: использованы методы источниковедческого анализа для выявления характерных особенностей уровня научной разработки проблемы; сравнительно-исторический для выяснения характерных особенностей образов музыкантов и подиумных моделей коллекций одежды известных дизайнеров; теоретического обобщения (для формулирования 
выводов). Научная новизна работы состоит в освещении процесса влияния сценических образов музыкантов на формирование современных трендов в дизайне одежды. На основании анализа жанровой принадлежности выяснены стилистические отличия сценического костюма популярных музыкальных исполнителей США и Европы. Отдельные стилистические характеристики сценической одежды артистов прослеживаются в коллекциях известных модных брендов XXI столетия, таких как Balenciaga, Philipp Plein, Vetements, Alexander Wang, Alexander McQueen и т. п. Выводы. В процессе исследования выявлены основные стилистические признаки сценического костюма исполнителей музыкальных жанров хард-рок и хеви-метал. Сценические образы артистов были новаторскими и нашли широкое использование в дизайне одежды XX и начала XXI столетия. Активное влияние музыкальных исполнителей на модные тенденции началось в 60-70-х годах XX в., что совпадает с развитием дизайна сценического костюма и значительным распространением медиа-технологий. Исполнители хард-рока и хеви-метала стали родоначальниками и активными популяризаторами такого стилевого направления, как «гранж», который является одним из ведущих в музыкальных тенденциях 2020-2021 гг. Много деталей и визуально-стилистических признаков и даже концепций для брендов дизайнеры XXI столетия позаимствовали у популярных хард-н-хеви исполнителей 1970-1990-х. Сценические образы музыкальных артистов значительно влияют на развитие моды и дизайна.

Ключевые слова: сценический костюм; мода; тренды; история музыки; рокмузыка; дизайн одежды 